\title{
Structural and Functional Characterization of RecG Helicase under Dilute and Molecular Crowding Conditions
}

\author{
Sarika Saxena, ${ }^{1,2}$ Satoru Nagatoishi, ${ }^{1}$ Daisuke Miyoshi, ${ }^{1,3}$ and Naoki Sugimoto ${ }^{1,3}$ \\ ${ }^{1}$ Frontier Institute for Biomolecular Engineering Research (FIBER), Konan University, 7-1-20 Minatojima-Minamimachi, \\ Chuo-ku, Kobe 650-0047, Japan \\ ${ }^{2}$ Amity Institute of Biotechnology, Amity University Uttar Pradesh, Sector-125, Expressway Highway, Noida 201303, India \\ ${ }^{3}$ Department of Nanobiochemistry, Faculty of Frontiers of Innovative Research in Science and Technology (FIRST), Konan University, \\ 7-1-20 Minatojima-Minamimachi, Chuo-ku, Kobe 650-0047, Japan
}

Correspondence should be addressed to Naoki Sugimoto, sugimoto@konan-u.ac.jp

Received 4 April 2012; Accepted 30 May 2012

Academic Editor: Masayasu Kuwahara

Copyright (c) 2012 Sarika Saxena et al. This is an open access article distributed under the Creative Commons Attribution License, which permits unrestricted use, distribution, and reproduction in any medium, provided the original work is properly cited.

In an ATP-dependent reaction, the Escherichia coli RecG helicase unwinds DNA junctions in vitro. We present evidence of a unique protein conformational change in the RecG helicase from an $\alpha$-helix to a $\beta$-strand upon an ATP binding under dilute conditions using circular dichroism (CD) spectroscopy. In contrast, under molecular crowding conditions, the $\alpha$-helical conformation was stable even upon an ATP binding. These distinct conformational behaviors were observed to be independent of $\mathrm{Na}^{+}$and $\mathrm{Mg}^{2+}$. Interestingly, CD measurements demonstrated that the spectra of a frayed duplex decreased with increasing of the RecG concentration both under dilute and molecular crowding conditions in the presence of ATP, suggesting that RecG unwound the frayed duplex. Our findings raise the possibility that the $\alpha$-helix and $\beta$-strand forms of RecG are a preactive and an active structure with the helicase activity, respectively.

\section{Introduction}

The double-stranded conformation of genomic DNA must be unwound to provide single-stranded DNA (ssDNA) intermediates required for DNA replication, recombination, and repair. The ssDNA intermediates can adopt various structures like junctions, G-quadruplex, and intramolecular triplex [1-3]. In cells, the unwinding of double-stranded DNA (dsDNA) is catalyzed by a class of ubiquitous enzymes termed DNA helicases [4]. Helicases disrupt one or more base pairs within the duplex DNA and then translocate vectorially to the next duplex region to repeat the process [5-9]. The helicase activity is cycled by the binding and hydrolysis of an NTP through a number of energetic (conformational) states that have different affinities for ssDNA and dsDNA $[10]$.

The structure of helicases plays a critical role in their catalytic functions. Previously, it was reported that almost all helicases appear to function as oligomers (usually dimers or hexamers) [10]. Oligomerization provides multiple binding sites necessary for DNA or RNA target recognition, interaction with accessory proteins, and ATP binding $[5,6]$. RecG is a well-characterized helicase from Escherichia coli that unwinds DNA junctions in vitro. Biochemical studies revealed that RecG is active as a monomer [11]. It catalyzes the interconversion of forks and junctions $[1,12,13]$. It is necessary in cellular processes such as DNA replication, recombination, and repair $[5,6]$. The conversion of a replication fork into a Holliday junction requires the simultaneous unwinding of the leading and lagging strands followed by the reannealing of the two parental strands and the annealing of the two nascent strands. There is no information available on the relationship between the structural states of RecG and its function. Any study to determine the mechanism of RecG action must, therefore, be addressing the differences between structural states of inactive and active forms of RecG.

Nucleic acids possess an intrinsic structural polymorphism critical in nucleic acid-nucleic acid, nucleic acidprotein, and nucleic acid-drug interactions. The polymorphic properties are influenced not only by sequence but 
also by surrounding conditions. The structures adopted are especially influenced by ionic properties like ion concentration, charge, and size [14-16]. Moreover, living cells contain soluble and insoluble molecules such as proteins, nucleic acids, saccharides, lipids, and metabolites that can alter the stabilities of canonical and noncanonical nucleic acid structures [17]. The total concentration of biomolecules reaches $400 \mathrm{~g} \mathrm{~L}^{-1}$ in cells, leading to what is referred to as molecular crowding [17, 18]. In the crowded intracellular environment, water activity decreases and hydration is unfavorable. These crowded conditions stabilize the noncanonical DNA structures such as triplexes and G-quadruplexes, whereas they destabilize the duplex form $[19,20]$. Elucidation of the interactions between helicases and DNA substrates with various structures is a very important step in understanding the mechanism through which helicases bind and unwind dsDNA. In this study, the structure and function of RecG were investigated under diluted and crowded conditions shedding light on how the structural properties of RecG correlate with activity.

\section{Materials and Methods}

2.1. DNA Sequences. DNA oligonucleotides of high performance liquid chromatography (HPLC) purification grade were purchased from Hokkaido System Science (see Table S1 in Supplementary Materials available online at doi:10.1155/2012/392039). Single-strand concentrations of the DNA sequences were determined by measuring absorbance at $260 \mathrm{~nm}$ at a high temperature using a Shimadzu 1700 spectrophotometer connected to a thermoprogrammer. Single-strand extinction coefficients were calculated from mononucleotide and dinucleotide data using the nearest neighbor approximation $[21,22]$.

2.2. Preparation of RecG. The gene encoding RecG was amplified using KOD-Plus DNA polymerase (Toyobo) with E. coli BL 21 genomic DNA as the template and the following primers: primer-S ( $5^{\prime}$-ggaattccatatgaaaggtcgcctgttagatg$\left.3^{\prime}\right)$ and primer-AS ( $5^{\prime}$-cccgctcgagtcatgcgttggagtaacgttc- $\left.3^{\prime}\right)$. Restriction enzyme sites for digestion and ligation are underlined. The PCR products were inserted into the NdeI and XhoI sites of the pET-26b vector (Merck). RecG was expressed with a hexahistidine tag attached at the $\mathrm{N}$ terminus.

RecG was expressed in E. coli strain Rosetta2 (DE3) at $28^{\circ} \mathrm{C}$ in $\mathrm{LB}$ medium supplemented with $30 \mathrm{mg} \mathrm{L}^{-1}$ kanamycin and $34 \mathrm{mg} \mathrm{L}^{-1}$ chloramphenicol. To induce RecG expression, isopropyl $\beta$-D-thiogalactopyranoside (IPTG) was added to a final concentration of $1 \mathrm{mM}$ when the optical density of the cells reached approximately 0.6 at $600 \mathrm{~nm}$. The culture was shaken overnight at $28^{\circ} \mathrm{C}$. The procedure for purification RecG was as follows: cells were suspended in $20 \mathrm{mM}$ Tris- $\mathrm{HCl}$ ( $\mathrm{pH} 8.5$ ), $100 \mathrm{mM} \mathrm{NaCl}$, and membranes were disrupted with a sonicator. The soluble fraction was loaded onto a HiTrap HP column (GE Healthcare). RecG was purified over a HisTrap HP column using buffer A $(20 \mathrm{mM}$ Tris ( $\mathrm{pH} 8.0)$ containing $100 \mathrm{mM} \mathrm{NaCl})$ and buffer $\mathrm{B}(20 \mathrm{mM}$
Tris ( $\mathrm{pH}$ 8.0) containing $2 \mathrm{M} \mathrm{NaCl}$ ) and then a HiLoad 26/60 Superdex 200-pg column (GE Healthcare) using buffer A (20 mM Tris ( $\mathrm{pH} 8.0$ ) containing $100 \mathrm{mM} \mathrm{NaCl}$ and $5 \mathrm{mM}$ imidazole) and buffer $\mathrm{B}(20 \mathrm{mM}$ Tris ( $\mathrm{pH} 8.0)$ containing $500 \mathrm{mM} \mathrm{NaCl}$ and $1 \mathrm{M}$ imidazole). Protein purity was confirmed by SDS-PAGE.

2.3. Circular Dichroism Measurements. Circular dichroism (CD) experiments were performed on a J-820 spectropolarimeter (Jasco) at $4^{\circ} \mathrm{C}$ and $37^{\circ} \mathrm{C}$ in a $0.1-\mathrm{cm}$ path length cuvette. Samples of $5 \mu \mathrm{M}$ RecG were prepared in $30 \mathrm{mM}$ MES (pH 7.0) and $0.5 \mathrm{mM} \mathrm{Na}{ }_{2}$ EDTA containing $100 \mathrm{mM} \mathrm{NaCl}$ or $100 \mathrm{mM} \mathrm{NaCl}$ and $1 \mathrm{mMMgCl}_{2}$ or $5 \mathrm{mM} \mathrm{MgCl}_{2}$, with and without $1 \mathrm{mM}$ ATP and $0 \mathrm{wt} \%$ or $40 \mathrm{wt} \%$ poly(ethylene glycol) with an average molecular mass of 200 (PEG 200). The CD spectra shown are the average of at least three scans from 200 to $350 \mathrm{~nm}$. The temperature of the cell holder was regulated by a temperature controller (PTC-348, Jasco), and the cuvette-holding chamber was flushed with a constant stream of dry $\mathrm{N}_{2}$ gas to avoid condensation of water on the cuvette exterior. CD melting curves of RecG were recorded at $222 \mathrm{~nm}$ in the presence of $30 \mathrm{mM}$ MES ( $\mathrm{pH} 7.0$ ) and $0.5 \mathrm{mM} \mathrm{Na}_{2}$ EDTA containing $100 \mathrm{mM} \mathrm{NaCl}$ or $100 \mathrm{mM} \mathrm{NaCl}$ and $1 \mathrm{mMMgCl}_{2}$ or $5 \mathrm{mM} \mathrm{MgCl}_{2}$ and $0 \mathrm{wt} \%$ or $40 \mathrm{wt} \%$ PEG 200. To analyze the functional activity of RecG, $1 \mu \mathrm{M}$ frayed duplex DNA was titrated with successive additions of $50 \mathrm{nM}$ RecG and $0.1 \mathrm{mM}$ ATP. Samples were prepared in the presence of $30 \mathrm{mM} \mathrm{MES}$ ( $\mathrm{pH} 7.0$ ) and $0.5 \mathrm{mM} \mathrm{Na} \mathrm{EDDT}_{2}$ containing $100 \mathrm{mM} \mathrm{NaCl}$ or $100 \mathrm{mM} \mathrm{NaCl}$ and $1 \mathrm{mM} \mathrm{MgCl}_{2}$ or $5 \mathrm{mM} \mathrm{MgCl}_{2}$. Before measurement, the frayed duplex DNA was heated to $95^{\circ} \mathrm{C}$, gently cooled at a rate of $0.5^{\circ} \mathrm{C} \mathrm{min}-1$, and incubated at $4^{\circ} \mathrm{C}$ overnight.

2.4. UV Melting Analysis. UV absorbance was measured with the Shimadzu spectrophotometer equipped with the temperature controller. Melting curves of DNA structures were obtained by measuring the UV absorbance at $260 \mathrm{~nm}$. Samples were prepared in $30 \mathrm{mM} \mathrm{MES}(\mathrm{pH} 7.0)$ and $0.5 \mathrm{mM}$ $\mathrm{Na}_{2}$ EDTA containing $100 \mathrm{mM} \mathrm{NaCl}$ or $100 \mathrm{mM} \mathrm{NaCl}$ and $1 \mathrm{mMMgCl}_{2}$ or $5 \mathrm{mMMgCl}_{2}$. Before measurement, the samples were heated to $95^{\circ} \mathrm{C}$, gently cooled at a rate of $0.5^{\circ} \mathrm{C} \mathrm{min}^{-1}$, and incubated at $4^{\circ} \mathrm{C}$ overnight. Measurement was performed using a $1-\mathrm{cm}$ path length cuvette. The melting temperature $\left(T_{m}\right)$ values for DNA structures were obtained from the UV melting curves as described previously [21, 22]. The heating rate was $0.5^{\circ} \mathrm{C} \mathrm{min}^{-1}$.

\section{Results and Discussion}

3.1. Structures of RecG under Dilute Conditions with and without ATP. Firstly, we used CD spectroscopy to study the structural states of RecG with and without ATP in the presence of different cations $\left(\mathrm{Na}^{+}, \mathrm{Mg}^{2+}\right.$, or both $\mathrm{Na}^{+}$and $\mathrm{Mg}^{2+}$ ) at $0 \mathrm{wt} \%$ and $40 \mathrm{wt} \%$ PEG 200, a neutral cosolute to study systematically the effects of molecular crowding. RecG was expressed in E. coli and purified by using ion exchange chromatography and affinity chromatography followed by 
dialysis. Figure 1(a) shows $\mathrm{CD}$ spectra at $4^{\circ} \mathrm{C}$ or $37^{\circ} \mathrm{C}$ of $5 \mu \mathrm{M}$ RecG in the presence of $100 \mathrm{mM} \mathrm{Na}^{+}$with or without ATP at $0 \mathrm{wt} \%$ PEG 200. The CD spectra without ATP displayed a positive peak at $198 \mathrm{~nm}$ and negative peaks at $208 \mathrm{~nm}$ and $220 \mathrm{~nm}$, which are characteristic of an $\alpha$-helix [23]. In the presence of $1 \mathrm{mM}$ ATP, the CD spectra of RecG had a positive peak at $195 \mathrm{~nm}$ and a negative peak at $225 \mathrm{~nm}$. These CD signatures are in agreement with formation of a $\beta$-strand structure [23].

The crystal structure of Thermotoga maritime RecG reveals three structural domains [24] (Figure S1). The largest domain (domain 1) is at $\mathrm{N}$-terminus, which forms a long $\alpha$ helix and a $\beta$-strand [25]. Domains 2 and 3 are referred to as helicase domains. The $\mathrm{C}$-terminal residues of the protein extend from the end of domain 3 and cross-back to contact domain 1 , forming a hook that wraps around the extended $\alpha$ helix, which provides a nucleotide binding site [24]. Recently, the structure of E. coli RecG was modeled based on the coordinates of Thermotoga maritime RecG usingSwiss-Pdb Viewer [26]. Apart from the missing N-terminal sequences that form a separate fold in the Thermotoga maritime RecG, the E. coli RecG structure is essentially identical [27]. Morikawa suggested that the insertion before the helicase core in the RecG sequence compared to the Thermotoga maritime RecG contributes to the specific recognition of the branched DNA structure by E. coli RecG [28]. The $\beta$-strand in the insertion domain recognizes the junction through a stacking interaction with several aromatic residues in RecG [24] (Figure S1). Thus, the $\alpha$-helix and the $\beta$ strand structures observed by the $\mathrm{CD}$ measurements likely correspond to the ATP binding domain and the DNA junction recognition structure, respectively.

We also measured the CD spectra of RecG as a function of ATP concentration from $0 \mathrm{mM}$ to $1 \mathrm{mM}$ under physiologically relevant ionic conditions $(100 \mathrm{mM} \mathrm{NaCl}$ and $1 \mathrm{mM} \mathrm{MgCl}_{2}$ ) at $37^{\circ} \mathrm{C}$ (Figure S2a). The CD spectra of RecG without ATP displayed a positive peak at $196 \mathrm{~nm}$ and negative peaks at $210 \mathrm{~nm}$ and $222 \mathrm{~nm}$ that remained unchanged at ATP concentrations below $0.17 \mathrm{mM}$. At ATP concentrations from $0.34 \mathrm{mM}$ to $1 \mathrm{mM}$, the $\mathrm{CD}$ spectra gradually shifted to a positive peak at $216 \mathrm{~nm}$ and a negative peak at $228 \mathrm{~nm}$. Figures S2b and S1c show the plots of molar ellipticity at $210 \mathrm{~nm}$ and $225 \mathrm{~nm}$, respectively, obtained from CD spectra versus increasing ATP concentration. The appearance of biphasic curves at $210 \mathrm{~nm}$ and $225 \mathrm{~nm}$ further confirms the structural transition. The difference of the transition points at $210 \mathrm{~nm}$ and at $225 \mathrm{~nm}$ might indicate that the dependency on ATP is different between the $\alpha$-helix and the $\beta$-strand conformations. These CD results clearly indicate that the $\alpha$-helix to $\beta$-strand transition in RecG depends on the ATP concentration.

3.2. Structures of RecG under Molecular Crowding Conditions with and without ATP. We also explored the effect of ATP binding on RecG under similar ionic conditions and a molecular crowding condition of $40 \mathrm{wt} \%$ PEG 200 (Figure 1(b)). CD spectra displayed positive peaks at $190 \mathrm{~nm}$ and $198 \mathrm{~nm}$ and negative peaks at $208 \mathrm{~nm}$ and $220 \mathrm{~nm}$ in the absence of ATP. In contrast to the spectra under the diluted conditions, no significant differences were observed in the $\mathrm{CD}$ spectra in the presence of 40\% PEG 200 even after the addition of ATP, indicating that $\alpha$-helix structure was dominant. In $100 \mathrm{mM} \mathrm{NaCl}$ and $1 \mathrm{mM} \mathrm{MgCl}_{2}$ (Figures S3a and S3b) or $5 \mathrm{mM} \mathrm{MgCl}_{2}$ (Figures S3c and S3d) at $0 \mathrm{wt} \%$ or $40 \mathrm{wt} \%$ PEG 200 , we observed that RecG without ATP folded into $\alpha$ helical conformation, whereas it was converted into the $\beta$ strand conformation after the addition of ATP. This result is identical to the result obtained with $100 \mathrm{mM} \mathrm{Na}^{+}$only, indicating that under dilute conditions the binding of ATP to RecG regulates the structural transition from an $\alpha$-helix to $\beta$-strand independent on the nature of cation. On the other hand, the cell-mimicking molecular crowding condition favored the folding of RecG into the $\alpha$-helical conformation even in the presence of ATP. Previous studies have shown that molecular crowders can stabilize the native state of a protein $[29,30]$, promote a oligomerization $[31,32]$, shift an open-closed equilibrium toward a closed form as a substratebinding state [17], and affect a folding rate of protein [3335]. Protein-folding variants are proposed to have key roles in a number of pathophysiological processes [36-40]. In view of published results that support the hypothesis that molecular crowding conditions are more relevant to the conditions in cells than dilute conditions, the ATP-independence of the RecG folding may have biological significance.

3.3. Thermal Stability of RecG under Dilute Conditions with and without ATP. To investigate in detail the structural changes induced in RecG upon ATP binding, we explored the thermal stability of RecG using CD melting at $222 \mathrm{~nm}$. Normalized CD melting curves of $5 \mu \mathrm{M}$ RecG in the presence of $100 \mathrm{mM} \mathrm{Na}^{+}$(Figure S4a), $100 \mathrm{mM} \mathrm{Na}^{+}$and $1 \mathrm{mM} \mathrm{Mg}^{2+}$ (Figure S4b), or $5 \mathrm{mM} \mathrm{Mg}^{2+}$ (Figure S4c) in the absence and presence of $1 \mathrm{mM}$ ATP were recorded. A single melting transition was observed in all the conditions. The estimated values of melting temperature $T_{1 / 2}$ (the temperature at which $50 \%$ of a protein sample is denatured) are given in Table S2. Addition of ATP stabilized the RecG by $3^{\circ} \mathrm{C}, 3.5^{\circ} \mathrm{C}$ and $1^{\circ} \mathrm{C}$ in the presence of $100 \mathrm{mM} \mathrm{Na}^{+}, 100 \mathrm{mM} \mathrm{Na}^{+}$and $1 \mathrm{mM}$ $\mathrm{Mg}^{2+}$, or $5 \mathrm{mM} \mathrm{Mg}^{2+}$, respectively. Close internal packing of the backbone atoms in $\beta$-strand structures of RecG optimizes van der Waals interactions and minimizes energetically unfavorable hydrophobic interactions between nonpolar protein groups and water molecules in the environment [41]. Collectively, these factors help to reduce the net free energy of the $\beta$-strand and thereby increase its stability. Our results suggest that RecG adopts its active functional structure after ATP binding to facilitate the process of unwinding of nucleic acid substrate, because ATP bindings play an important role in the functional activity of various proteins [42-45].

3.4. Thermal Stability of RecG under Molecular Crowding Conditions with and without ATP. In the absence of ATP, RecG was stabilized by $2^{\circ} \mathrm{C}, 1.0^{\circ} \mathrm{C}$, and $2.5^{\circ} \mathrm{C}$ in the presence of $100 \mathrm{mM} \mathrm{Na}^{+}, 100 \mathrm{mM} \mathrm{Na}^{+}$and $1 \mathrm{mM} \mathrm{Mg}^{2+}$, or $5 \mathrm{mM} \mathrm{Mg}^{2+}$ respectively at $40 \mathrm{wt} \%$ PEG 200 in comparison to $0 \mathrm{wt} \%$ PEG 200. Furthermore, addition of ATP thermally stabilized the RecG at $40 \mathrm{wt} \%$ PEG 200, and RecG was maximally 


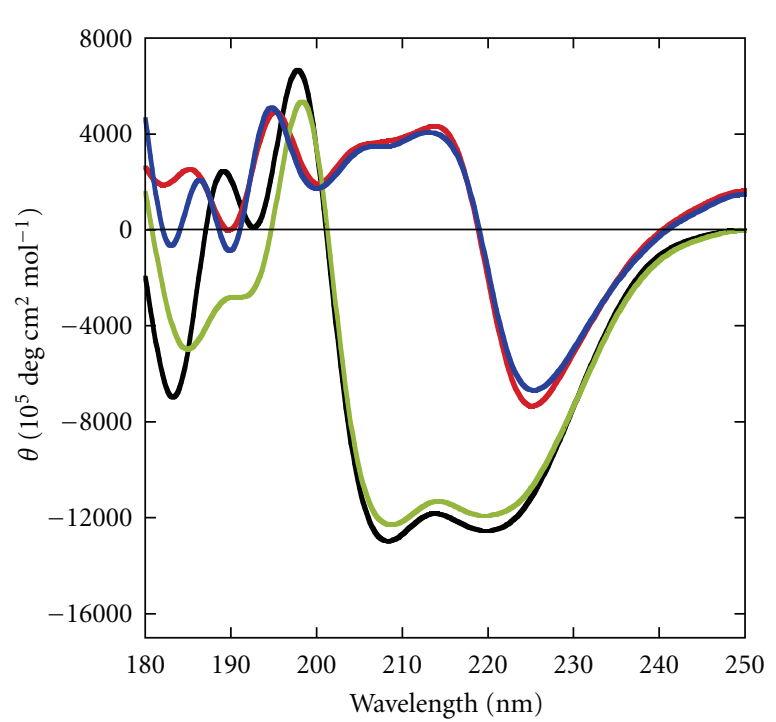

(a)

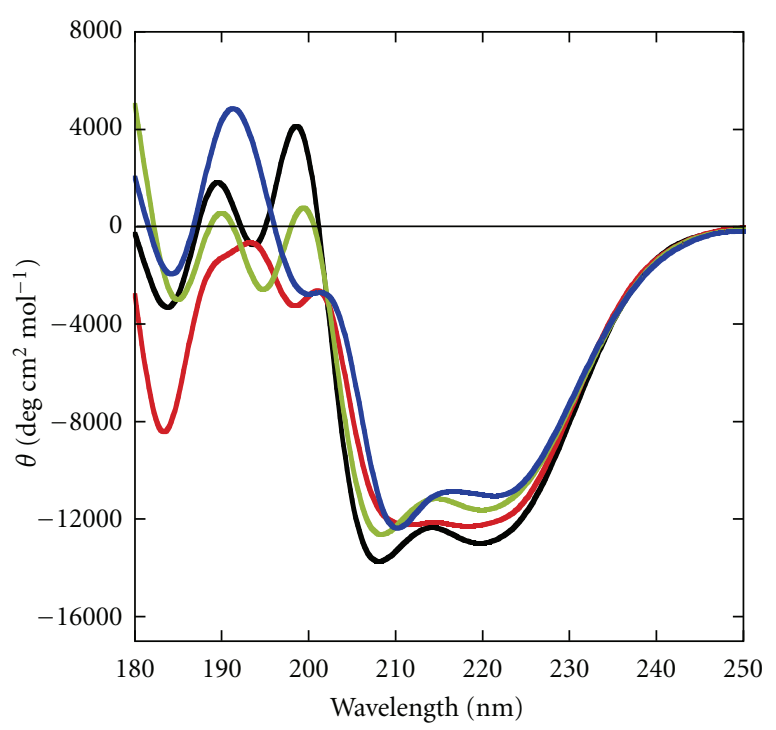

(b)

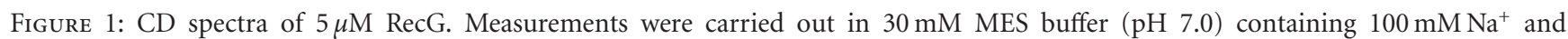
$0.5 \mathrm{mM} \mathrm{Na}_{2} \mathrm{EDTA}$ (a) at $0 \mathrm{wt} \%$ PEG 200 without ATP at $4^{\circ} \mathrm{C}$ (black) and $37^{\circ} \mathrm{C}$ (green), or with $1 \mathrm{mM} \mathrm{ATP}$ at $4^{\circ} \mathrm{C} \mathrm{(red)} \mathrm{and} 37^{\circ} \mathrm{C}(\mathrm{blue})$, and (b) at $40 \mathrm{wt} \%$ PEG 200 without ATP at $4^{\circ} \mathrm{C}$ (black) and $37^{\circ} \mathrm{C}$ (green), or with $1 \mathrm{mM} \mathrm{ATP}$ at $4^{\circ} \mathrm{C}$ (red) and $37^{\circ} \mathrm{C}$ (blue), respectively.

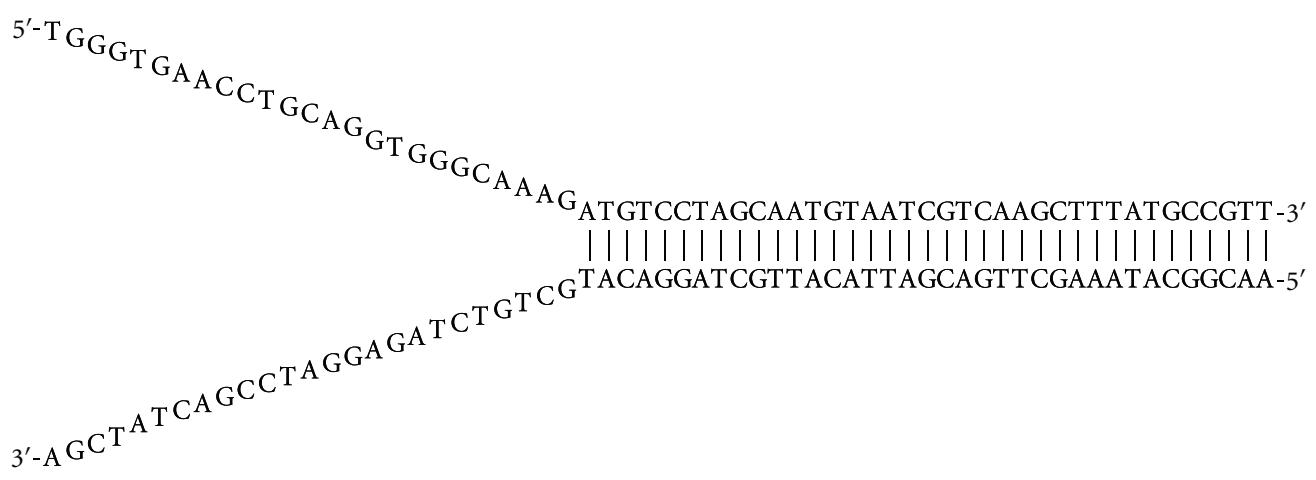

Figure 2: A nucleotide target sequence of frayed duplex.

stable $\left(T_{1 / 2}=50^{\circ} \mathrm{C}\right)$ at $40 \mathrm{wt} \%$ PEG 200 in the presence of ATP. Folded proteins usually have hydrophobic cores and charged or polar side-chains occupy the solvent-exposed surface. Minimizing the number of hydrophobic side chains exposed to water is an important driving force behind the folding process [46]. Formation of intramolecular hydrogen bonds provides another important contribution to protein stability [47]. The strength of hydrogen bonds depends on their environment, thus hydrogen bonds enveloped in a hydrophobic core contribute more than hydrogen-bonds exposed to the aqueous environment [48]. Under molecular crowding conditions, low water activity may induce the interdomain rearrangement in RecG to allow formation of the $\alpha$ helix containing a hydrophobic core. The $\alpha$-helix form was stabilized by $2^{\circ} \mathrm{C}\left(T_{1 / 2}=50^{\circ} \mathrm{C}\right)$ at $40 \mathrm{wt} \%$ PEG 200 than at $0 \mathrm{wt} \%$ PEG $200\left(T_{1 / 2}=48^{\circ} \mathrm{C}\right)$ in the presence of $5 \mathrm{mM} \mathrm{Mg}^{2+}$.
3.5. Thermal Stability of Frayed Duplex under Dilute and Molecular Crowding Conditions. We designed a 62-mer DNA oligonucleotide to form a frayed DNA duplex containing noncomplementary arms and a stem region (Figure 2 ). This arrangement of bases within the target duplex mimics that of a replication fork. The single-stranded non-complementary arms should facilitate the binding of RecG. The enzyme should then translocate to the dsDNA to allow the strand separation with a $3^{\prime}-5^{\prime}$ polarity. The ssDNA extension was introduced at the $5^{\prime}$ end to stimulate the activity of RecG on the strand opposite to that used for the primary contact of RecG.

We first measured the stability of frayed duplex by recording the UV melting of $1 \mu \mathrm{M}$ DNA duplex in the presence of $100 \mathrm{mM} \mathrm{Na}^{+}$(Figure S5a), $100 \mathrm{mM} \mathrm{Na}^{+}$and $1 \mathrm{mM} \mathrm{Mg}^{2+}$ (Figure S5b), and $5 \mathrm{mMMg}^{2+}$ (Figure S5c) at 


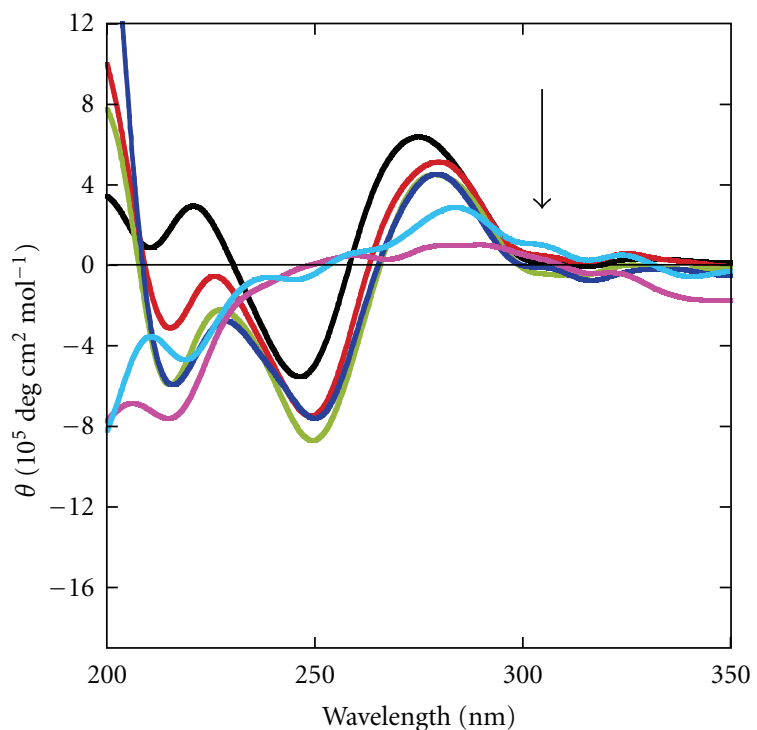

(a)

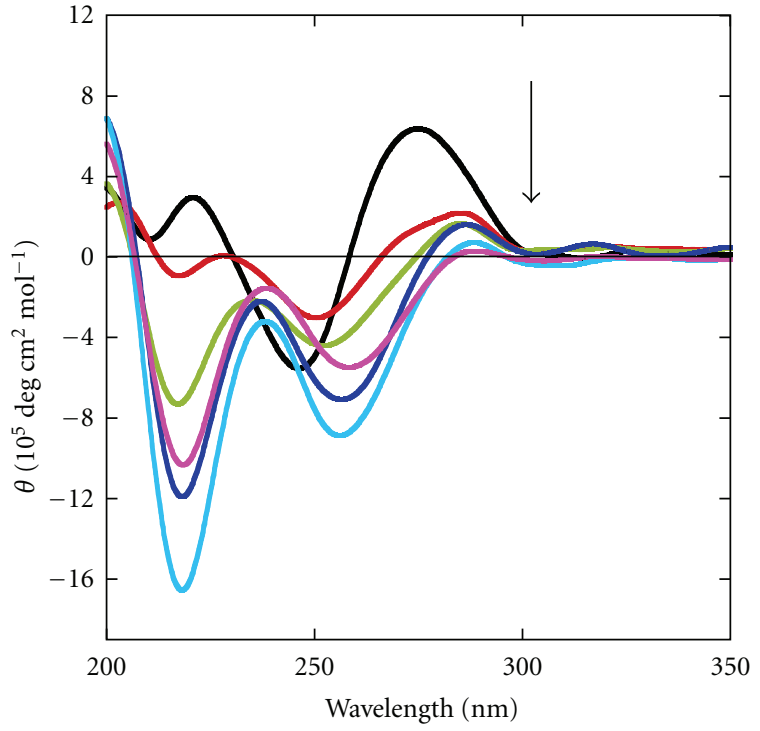

(b)

FIGURE 3: CD spectra of $1 \mu \mathrm{M}$ DNA frayed duplex. Measurements were carried out at $37^{\circ} \mathrm{C}$ in $30 \mathrm{mM} \mathrm{MES}$ buffer (pH 7.0 ) containing $100 \mathrm{mM} \mathrm{Na}^{+}, 0.5 \mathrm{mM} \mathrm{Na} 2$ EDTA, RecG $(0 \mathrm{nM})$ and ATP $(0 \mathrm{mM})$ (black), RecG $(50 \mathrm{nM})$ and ATP $(0.1 \mathrm{mM})$ (red), RecG (100 nM) and ATP (0.2 mM ) (green), RecG (150 nM) and ATP (0.3 mM, blue), RecG (200 nM) and ATP (0.4 mM, cyan), and RecG (250 nM) and ATP (0.5 mM) (pink), at (a) $0 \mathrm{wt} \%$ PEG 200 and (b) $40 \mathrm{wt} \%$ PEG 200.

$0 \mathrm{wt} \%$ or $40 \mathrm{wt} \%$ PEG 200. We observed two transitions for the thermal melting of the frayed duplex. The lower temperature transition could be due to the intramolecular interaction of the bases constituting the arm region of the frayed duplex. The higher-temperature transition could be due to the melting of the stem region. In the absence of PEG 200, the mid-points of the higher-temperature transitions were $70^{\circ} \mathrm{C}, 71^{\circ} \mathrm{C}$, and $72^{\circ} \mathrm{C}$ in the presence of $100 \mathrm{mM} \mathrm{Na}^{+}$, $100 \mathrm{mM} \mathrm{Na}^{+}$and $1 \mathrm{mM} \mathrm{Mg}^{2+}$, and $5 \mathrm{mM} \mathrm{Mg}^{2+}$, respectively. In $40 \mathrm{wt} \%$ PEG 200, the higher-temperature transitions in the presence of $100 \mathrm{mM} \mathrm{Na}^{+}, 100 \mathrm{mM} \mathrm{Na}^{+}$and $1 \mathrm{mM} \mathrm{Mg}^{2+}$, and $5 \mathrm{mM} \mathrm{Mg}^{2+}$ were $65^{\circ} \mathrm{C}, 66^{\circ} \mathrm{C}$, and $66^{\circ} \mathrm{C}$, respectively. To confirm the higher melting transition due to stem region, we have also recorded the stability of stem region of frayed duplex by recording the UV melting of $1 \mu \mathrm{M}$ DNA duplex in the presence of $100 \mathrm{mM} \mathrm{Na}^{+}$(Figure S5a), $100 \mathrm{mM} \mathrm{Na}^{+}$ and $1 \mathrm{mM} \mathrm{Mg}^{2+}$ (Figure S5b), and $5 \mathrm{mM} \mathrm{Mg}^{2+}$ (Figure S5c) at $0 \mathrm{wt} \%$ or $40 \mathrm{wt} \%$ PEG 200. We observed single transition for the thermal melting of the stem region of frayed duplex which confirms that upper transition in frayed duplex is due to the intermolecular structure (Figure S6). In the absence of PEG 200, the mid-points of the highertemperature transitions were $74^{\circ} \mathrm{C}, 74.5^{\circ} \mathrm{C}$, and $74.5^{\circ} \mathrm{C}$ in the presence of $100 \mathrm{mM} \mathrm{Na}^{+}, 100 \mathrm{mM} \mathrm{Na}^{+}$and $1 \mathrm{mM} \mathrm{Mg}^{2+}$, and $5 \mathrm{mM} \mathrm{Mg}^{2+}$, respectively. In $40 \mathrm{wt} \%$ PEG 200, the highertemperature transitions in the presence of $100 \mathrm{mM} \mathrm{Na}^{+}$, $100 \mathrm{mM} \mathrm{Na}^{+}$and $1 \mathrm{mM} \mathrm{Mg}^{2+}$, and $5 \mathrm{mM} \mathrm{Mg}^{2+}$ were $74^{\circ} \mathrm{C}$, $67^{\circ} \mathrm{C}$ and $66^{\circ} \mathrm{C}$, respectively. The decrease in the $T_{1 / 2}$ values under molecular crowding conditions is in good agreement with previous reports of DNA duplex stabilities in molecular crowders [49].
3.6. Functional Activity of RecG under Dilute Conditions. The CD spectrum of the DNA in the presence of $100 \mathrm{mM} \mathrm{Na}^{+}$ without PEG 200 was characterized by a positive peak at $275 \mathrm{~nm}$ and negative peaks at $211 \mathrm{~nm}$ and $247 \mathrm{~nm}$, a spectrum typical of the B-form conformation [50] (Figure 3). We then added RecG and ATP to the DNA. At $50 \mathrm{nM}$ RecG and $0.1 \mathrm{mM}$ ATP, we observed a decrease in intensity of the positive peak at $275 \mathrm{~nm}$ and a red shift such that negative peaks were located at $215 \mathrm{~nm}$ and $250 \mathrm{~nm}$ (Figure 3(a)). There was no signal from RecG due to the low concentration. Spectra were recorded after successive additions of RecG and ATP, and after each addition we observed a decrease in intensity of the positive peak. At $250 \mathrm{nM}$ RecG and $0.5 \mathrm{mM}$ ATP, there was complete loss in original B-form conformation of the DNA, indicating unwinding of the duplex. Previous report described the role of RecG in the processing of stalled replication forks, and acted by reversing the fork past the damage to create a four-way junction that allows template switching and lesion bypass [24]. It has also been reported that RecG unwinds both the leading and lagging strand duplex arms of a three-way junction and the unwinding of these arms was found to be coordinated [24]. In our study, as frayed duplex contains only single-stranded long overhangs at both the terminus, therefore, we propose that RecG should bind to the frayed duplex (as it mimics the replication fork) and should convert the duplex into single strands. Therefore, to confirm the same we have recorded the $\mathrm{CD}$ spectra of single stands constituting the frayed duplex under dilute and molecular crowding conditions (Figure S7). The CD spectrum of each single strand of frayed duplex in the presence of $100 \mathrm{mM} \mathrm{Na}^{+}, 100 \mathrm{mM} \mathrm{Na}^{+}$and 
$1 \mathrm{mMMg}^{2+}$, and $5 \mathrm{mMMg}^{2+}$ with and without PEG 200 was characterized by a positive peak at $274 \mathrm{~nm}$ and negative peaks at $244 \mathrm{~nm}$. These CD signatures indicate that each single strand of the frayed duplex folds into typical of the Bform conformation due to the formation of intramolecular structure. To better understand the structures of frayed duplex after unwinding by RecG, secondary structures of single strands were predicted using $\mathrm{M}$-fold $[51,52]$. The monomers of frayed duplex showed 3 short complementary stems with a varying number of bases in loops along with short dangling ends at opposite terminus in each strand (Figure S8). When CD spectra were recorded after successive additions of RecG and ATP, and after each addition, we observed a decrease in intensity of the positive peak (Figure 3 and Figure S9). At $250 \mathrm{nM} \mathrm{RecG}$ and $0.5 \mathrm{mM}$ ATP, there was complete loss in original B-form conformation of the DNA, indicating unwinding of the duplex into single strands solely due to the enzymatic activity of RecG in the presence of ATP. Earlier studies indicated that the substrate specificity of RecG was critically dependent on the concentrations of ATP and $\mathrm{MgCl}_{2}$, and under certain conditions, RecG preferentially unwound three strand junctions of DNA $[1,11]$. Here, we observed functional activity of RecG in the presence of $\mathrm{Na}^{+}$ and absence of $\mathrm{Mg}^{2+}$.

Next, we recorded the CD spectra in the presence of $100 \mathrm{mM} \mathrm{Na}^{+}$and $1 \mathrm{mMMg}^{2+}$ (Figure S9a) and in $100 \mathrm{mM} \mathrm{Na}^{+}$and $5 \mathrm{mM} \mathrm{Mg}^{2+}$ (Figure S9b) without PEG 200. We observed an overall decrease in CD ellipticity at $273 \mathrm{~nm}$ that shifted to $283 \mathrm{~nm}$ after the successive additions of RecG and ATP, although the extent of decrease of the positive peak was observed to be less than that observed without $\mathrm{Mg}^{2+}$. These results clearly indicate that the functional activity of RecG was not dependent on the nature of the cations. A recent paper showed that the conformational change of the DNA-binding domain of hel 308 helicase, which is a member of the same superfamily-2 helicase family as RecG, is coordinated by the ATP binding [53]. As we observed a structural transition from an $\alpha$-helix to $\beta$-strand upon ATP binding under dilute conditions (Figure $1(\mathrm{a})$ ) and functional activity under the same conditions, we propose that the $\beta$ strand structure is the conformation of RecG that unwinds our DNA substrate under dilute conditions. The $\beta$-strand structure could function as a "helix opener" by actively disrupting base pairs of a frayed DNA duplex, and this may be the basis of recognition of DNA junctions.

3.7. Functional Activity of $\operatorname{Rec} G$ under Molecular Crowding Conditions. To evaluate the effect of molecular crowding, we repeated our analysis of the activity of RecG in solution containing $40 \mathrm{wt} \%$ PEG 200. The CD spectra of the DNA were measured in $100 \mathrm{mM} \mathrm{Na}^{+}$(Figure $3(\mathrm{~b})$ ), $100 \mathrm{mM} \mathrm{Na}^{+}$ and $1 \mathrm{mM} \mathrm{Mg}^{2+}$ (Figure S9c), and $5 \mathrm{mM} \mathrm{Mg}^{2+}$ (Figure S9d) in $40 \mathrm{wt} \%$ PEG 200. Of note, the conformation of the frayed duplex is different in $40 \mathrm{wt} \%$ PEG 200 than in $0 \mathrm{wt} \%$ PEG 200 , as mentioned above stability of the frayed duplex was found to be lower under molecular crowding conditions than under dilute conditions. In $100 \mathrm{mM} \mathrm{Na}^{+}$in the presence of the crowding agent, the positive peak at $275 \mathrm{~nm}$ shifted to $288 \mathrm{~nm}$ after the successive addition of $50 \mathrm{nM}$ RecG and
$0.1 \mathrm{mM}$ ATP. This indicates the catalytic activity of RecG under molecular crowding conditions is different from that under the dilute conditions.

Similar decreases in intensities of the positive peak at $275 \mathrm{~nm}$ and the negative peaks at $221 \mathrm{~nm}$ and $247 \mathrm{~nm}$ were observed when RecG and ATP were added to the frayed duplex in the presence of $100 \mathrm{mM} \mathrm{Na}^{+}$and either $1 \mathrm{mM} \mathrm{Mg}^{2+}$ or $5 \mathrm{mM} \mathrm{Mg}^{2+}$ and $40 \mathrm{wt} \%$ PEG 200 (Figures S9c and S9d). These CD results clearly indicate that RecG unwound the frayed duplex both under dilute and molecular crowding condition independent on the nature of cations, although it is quite possible that the extent of unwinding of frayed duplex and catalytic efficiency of RecG may depend on the nature of cation.

\subsection{Possible Relationship between the Structure and the} Function of RecG. In the absence of crowder and in the presence of ATP, RecG was converted from an $\alpha$-helix form to a $\beta$-strand form. Under the crowding conditions, on the other hand, RecG remained in $\alpha$-helix form even when ATP was added. The ATP binding site of RecG is in domains 2 and 3 which both have $\alpha$-helical conformations [25]. It has been reported that the SecA helicase, which has homologous structure and function to RecG undergoes a transition to an $\alpha$-helix form upon ATP binding [54]. Therefore, the $\alpha$-helix form of RecG is likely essential for ATP binding. The conformational change to $\beta$-strand form observed in this study may suggest a transition to the active DNAbinding form of RecG. Based on our results, we propose that the $\beta$-strand form observed under diluted conditions is the active structure for binding and unwinding of DNA, whereas the $\alpha$-helix form observed under the crowded conditions is the preactive structure that stably binds ATP. The different unwinding activities observed may be due to the interdomain flexibility of RecG, which allows substantial conformational changes imparting the ability to recognize more than one DNA structure. Furthermore, our results can provide significant information to explore and design the small ligands regulating the RecG helicase activity with a molecular crowding condition.

\section{Conclusion}

The data presented in this study emphasize some important points. Firstly, the secondary structures of RecG were different with and without a molecular crowding agent, PEG 200. The structural transition from $\alpha$-helix to $\beta$-strand observed under the dilute conditions depended solely on the binding of ATP and not on the nature of cations present in solution. The molecular crowding conditions favored the folding of RecG bound to ATP into an $\alpha$-helical structure. This may be a consequence of hydration. Secondly, the frayed duplex was unwound by RecG under dilute and molecular crowding conditions, indicating that the $\beta$-strand conformation may be the active structure of RecG, with the $\alpha$-helix form the pre-active structure of RecG. Molecular crowding conditions played a critical role in the functional structure of RecG, and our data suggest the reason for 
the observed differences in the unwinding activity in vivo and in vitro. We are currently working to determine the binding stoichiometry of ATP with RecG and to quantify functional activity of RecG under dilute and molecular crowding conditions on various DNA substrates.

\section{Acknowledgments}

This work was supported in part by Grants-in-Aid for Scientific Research, the "Core research" project (2009-2014) from the Ministry of Education, Culture, Sports, Science and Technology, Japan, and the Hirao Taro Foundation of the Konan University Association for Academic Research and the research grant of "Department of Science and Technology (DST)," Govt of India, (SERC/LS-0594/2010).

\section{References}

[1] P. McGlynn and R. G. Lloyd, "RecG helicase activity at threeand four-strand DNA structures," Nucleic Acids Research, vol. 27, no. 15, pp. 3049-3056, 1999.

[2] R. Giraldo, M. Suzuki, L. Chapman, and D. Rhodes, "Promotion of parallel DNA quadruplexes by a yeast telomere binding protein: a circular dichroism study," Proceedings of the National Academy of Sciences of the United States of America, vol. 91, no. 16, pp. 7658-7662, 1994.

[3] R. M. Brosh, A. Majumdar, S. Desai, I. D. Hickson, V. A. Bohr, and M. M. Seidman, "Unwinding of a DNA triple helix by the werner and bloom syndrome helicases," Journal of Biological Chemistry, vol. 276, no. 5, pp. 3024-3030, 2001.

[4] S. W. Matson and K. A. Kaiser-Rogers, "DNA helicases," Annual Review of Biochemistry, vol. 59, pp. 289-329, 1990.

[5] T. M. Lohman, "Escherichia coli DNA helicases: mechanisms of DNA unwinding," Molecular Microbiology, vol. 6, no. 1, pp. 5-14, 1992.

[6] T. M. Lohman, "Helicase-catalyzed DNA unwinding," Journal of Biological Chemistry, vol. 268, no. 4, pp. 2269-2272, 1993.

[7] G. T. Yarranton and M. L. Gefter, "Enzyme-catalyzed DNA unwinding: studies on Escherichia coli Rep protein," Proceedings of the National Academy of Sciences of the United States of America, vol. 76, no. 4, pp. 1658-1662, 1979.

[8] N. Arai, K. I. Arai, and A. Kornberg, "Complexes of Rep protein with ATP and DNA as a basis for helicase action," Journal of Biological Chemistry, vol. 256, no. 10, pp. 52875293, 1981.

[9] I. Wong and T. M. Lohman, "Allosteric effects of nucleotide cofactors on Escherichia coli Rep helicase-DNA binding," Science, vol. 256, no. 5055, pp. 350-355, 1992.

[10] K. J. M. Moore and T. M. Lohman, "Helicase-catalyzed DNA unwinding: energy coupling by DNA motor proteins," Biophysical Journal, vol. 68, supplement 4, pp. 180s-185s, 1995.

[11] P. McGlynn, A. A. Mahdi, and R. G. Lloyd, "Characterisation of the catalytically active form of RecG helicase," Nucleic Acids Research, vol. 28, no. 12, pp. 2324-2332, 2000.

[12] P. McGlynn and R. G. Lloyd, "Modulation of RNA polymerase by (p)ppGpp reveals a RecG-dependent mechanism for replication fork progression," Cell, vol. 101, no. 1, pp. 35-45, 2000.

[13] P. McGlynn, R. G. Lloyd, and K. J. Marians, "Formation of Holliday junctions by regression of nascent DNA in intermediates containing stalled replication forks: RecG stimulates regression even when the DNA is negatively supercoiled,"
Proceedings of the National Academy of Sciences of the United States of America, vol. 98, no. 15, pp. 8235-8240, 2001.

[14] G. S. Manning, "On the application of polyelectrolyte "limiting laws" to the helix-coil transition of DNA. I. Excess univalent cations," Biopolymers, vol. 11, no. 5, pp. 937-949, 1972.

[15] M. T. Record Jr., C. F. Anderson, and T. M. Lohman, "Thermodynamic analysis of ion effects on the binding and conformational equilibria of proteins and nucleic acids: the roles of ion association or release, screening, and ion effects on water activity," Quarterly Reviews of Biophysics, vol. 11, no. 2, pp. 103-178, 1978.

[16] C. F. Anderson and M. T. Record, "Ion distributions around DNA and other cylindrical polyions: theoretical descriptions and physical implications," Annual Review of Biophysics and Biophysical Chemistry, vol. 19, pp. 423-465, 1990.

[17] H. Dong, S. Qin, and H. X. Zhou, "Effects of macromolecular crowding on protein conformational changes," PLoS computational biology, vol. 6, p. e1000833, 2010.

[18] D. Miyoshi and N. Sugimoto, "Molecular crowding effects on structure and stability of DNA," Biochimie, vol. 90, no. 7, pp. 1040-1051, 2008.

[19] D. Miyoshi, K. Nakamura, K. Tateishi, T. Ohmichi, and N. Sugimoto, "Hydration of watson crick base pairs and dehydration of hoogsteen base pairs inducing structural polymorphism under molecular crowding conditions," Journal of the American Chemical Society, vol. 131, no. 10, pp. 3522-3531, 2009.

[20] H. X. Zhou, G. Rivas, and A. P. Minton, "Macromolecular crowding and confinement: biochemical, biophysical, and potential physiological consequences," Annual Review of Biophysics, vol. 37, pp. 375-397, 2008.

[21] N. Sugimoto, S. I. Nakano, M. Katoh et al., "Thermodynamic parameters to predict stability of RNA/DNA hybrid duplexes," Biochemistry, vol. 34, no. 35, pp. 11211-11216, 1995.

[22] S. I. Nakano, T. Kanzaki, and N. Sugimoto, "Influences of ribonucleotide on a duplex conformation and its thermal stability: study with the chimeric RNA-DNA strands," Journal of the American Chemical Society, vol. 126, no. 4, pp. 10881095, 2004.

[23] M. K. Sharon, J. J. Thomas, and C. P. Nicholas, "How to study proteins by circular dichroism," Biochimica et Biophysica Acta, vol. 1751, no. 2, pp. 119-139, 2005.

[24] M. R. Singleton, S. Scaife, and D. B. Wigley, "Structural analysis of DNA replication fork reversal by RecG," Cell, vol. 107, no. 1, pp. 79-89, 2001.

[25] A. A. Mahdi, P. McGlynn, S. D. Levett, and R. G. Lloyd, "DNA binding and helicase domains of the Escherichia coli recombination protein RecG," Nucleic Acids Research, vol. 25, no. 19, pp. 3875-3880, 1997.

[26] N. Guex and M. C. Peitsch, "SWISS-MODEL and the SwissPdbViewer: an environment for comparative protein modeling," Electrophoresis, vol. 18, no. 15, pp. 2714-2723, 1997.

[27] G. S. Briggs, A. A. Mahdi, G. R. Weller, Q. Wen, and R. G. Lloyd, "Interplay between DNA replication, recombination and repair based on the structure of RecG helicase," Philosophical Transactions of the Royal Society B, vol. 359, no. 1441, pp. 49-59, 2004.

[28] T. Nishino, K. Komori, D. Tsuchiya, Y. Ishino, and K. Morikawa, "Crystal structure and functional implications of Pyrococcus furiosus Hef helicase domain involved in branched DNA processing," Structure, vol. 13, no. 1, pp. 143-153, 2005.

[29] K. Sasahara, P. McPhie, and A. P. Minton, "Effect of dextran on protein stability and conformation attributed to 
macromolecular crowding," Journal of Molecular Biology, vol. 326, no. 4, pp. 1227-1237, 2003.

[30] D. S. Spencer, K. Xu, T. M. Logan, and H. X. Zhou, "Effects of $\mathrm{pH}$, salt, and macromolecular crowding on the stability of FK506-binding protein: an integrated experimental and theoretical study," Journal of Molecular Biology, vol. 351, no. 1, pp. 219-232, 2005.

[31] S. B. Qin and H.-X. Zhou, "Atomistic modeling of macromolecular crowding predicts modest increases in protein folding and binding stability," Biophysical Journal, vol. 97, no. 1, pp. 12-19, 2009.

[32] J. Batra, K. Xu, S. B. Qin, and H. X. Zhou, "Effect of macromolecular crowding on protein binding stability: modest stabilization and significant biological consequences," Biophysical Journal, vol. 97, no. 3, pp. 906-911, 2009.

[33] B. van den Berg, R. J. Ellis, and C. M. Dobson, "Effects of macromolecular crowding on protein folding and aggregation," The EMBO Journal, vol. 18, no. 24, pp. 6927-6933, 1999.

[34] R. J. Ellis, "Macromolecular crowding: obvious but underappreciated," Trends in Biochemical Sciences, vol. 26, no. 10, pp. 597-604, 2001.

[35] X. Ai, Z. Zhou, Y. Bai, and W. Y. Choy, "15N NMR spin relaxation dispersion study of the molecular crowding effects on protein folding under native conditions," Journal of the American Chemical Society, vol. 128, no. 12, pp. 3916-3917, 2006.

[36] J. Martin and F. U. Hartl, "Chaperone-assisted protein folding," Current Opinion in Structural Biology, vol. 7, no. 1, pp. 41-52, 1997.

[37] F. G. van der Goot, J. M. Gonzalez-Manas, J. H. Lakey, and F. Pattus, "A "molten-globule" membrane-insertion intermediate of the pore-forming domain of colicin A," Nature, vol. 354, no. 6352, pp. 408-410, 1991.

[38] J. Safar, H. Wille, V. Itri et al., "Eight prion strains have $\operatorname{PrP}(\mathrm{Sc})$ molecules with different conformations," Nature Medicine, vol. 4, no. 10, pp. 1157-1165, 1998.

[39] J. S. Dennis, "Folding proteins in fatal ways," Nature, vol. 426, no. 6968, pp. 900-904, 2003.

[40] F. Chiti and C. M. Dobson, "Protein misfolding, functional amyloid, and human disease," Annual Review of Biochemistry, vol. 75, pp. 333-366, 2006.

[41] V.Smirnovas, R. Winter, T. Funck, and W. Dzwolak, "Thermodynamic properties underlying the $\alpha$-helix-to- $\beta$-sheet transition, aggregation, and amyloidogenesis of polylysine as probed by calorimetry, densimetry, and ultrasound velocimetry," Journal of Physical Chemistry B, vol. 109, no. 41, pp. 1904319045, 2005.

[42] M. Saraste, P. R. Sibbald, and A. Wittinghofer, "The P-loop - a common motif in ATP- and GTP-binding proteins," Trends in Biochemical Sciences, vol. 15, no. 11, pp. 430-434, 1990.

[43] T. W. Traut, "The functions and consensus motifs of nine types of peptide segments that form different types of nucleotidebinding sites," European Journal of Biochemistry, vol. 222, no. 1, pp. 9-19, 1994.

[44] S. Klumpp, D. Kriha, G. Bechmann et al., "Phosphorylation of the growth factors bFGF, NGF and BDNF: a prerequisite for their biological activity," Neurochemistry International, vol. 48, no. 2, pp. 131-137, 2006.

[45] K. Rose, R. E. Gast, A. Seeger, J. Krieglstein, and S. Klumpp, "ATP-dependent stabilization and protection of fibroblast growth factor 2," Journal of Biotechnology, vol. 145, no. 1, pp. $54-59,2010$.
[46] C. N. Pace, B. A. Shirley, M. Mcnutt, and K. Gajiwala, "Forces contributing to the conformational stability of proteins," The FASEB Journal, vol. 10, no. 1, pp. 75-83, 1996.

[47] G. D. Rose, P. J. Fleming, J. R. Banavar, and A. Maritan, "A backbone-based theory of protein folding," Proceedings of the National Academy of Sciences of the United States of America, vol. 103, no. 45, pp. 16623-16633, 2006.

[48] S. Deechongkit, H. Nguyen, P. E. Dawson, M. Gruebele, J. W. Kelly, and E. T. Powers, "Context-dependent contributions of backbone hydrogen bonding to $\beta$-sheet folding energetics," Nature, vol. 430, no. 6995, pp. 101-105, 2004.

[49] D. Miyoshi, S. Matsumura, S. I. Nakano, and N. Sugimoto, "Duplex dissociation of telomere DNAs induced by molecular crowding," Journal of the American Chemical Society, vol. 126, no. 1, pp. 165-169, 2004.

[50] W. C. Johnson, "CD of nucleic acids," in Circular Dichroism: Principles and Applications, K. Nakanishi, N. Berova, and R. W. Woody, Eds., pp. 523-540, Wiley-VCH, New York, NY, USA, 1994.

[51] M. Zuker, "Mfold web server for nucleic acid folding and hybridization prediction," Nucleic Acids Research, vol. 31, no. 13, pp. 3406-3415, 2003.

[52] D. H. Mathews, M. D. Disney, J. L. Childs, S. J. Schroeder, M. Zuker, and D. H. Turner, "Incorporating chemical modification constraints into a dynamic programming algorithm for prediction of RNA secondary structure," Proceedings of the National Academy of Sciences of the United States of America, vol. 101, no. 19, pp. 7287-7292, 2004.

[53] K. Büttner, S. Nehring, and K.-P. Hopfner, "Structural basis for DNA duplex separation by a superfamily-2 helicase," Nature Structural \& Molecular Biology, vol. 14, no. 7, pp. 647-652, 2007.

[54] D. Keramisanou, N. Biris, I. Gelis et al., "Disorder-order folding transitions underlie catalysis in the helicase motor of SecA," Nature Structural \& Molecular Biology, vol. 13, no. 7, pp. 594-602, 2006. 

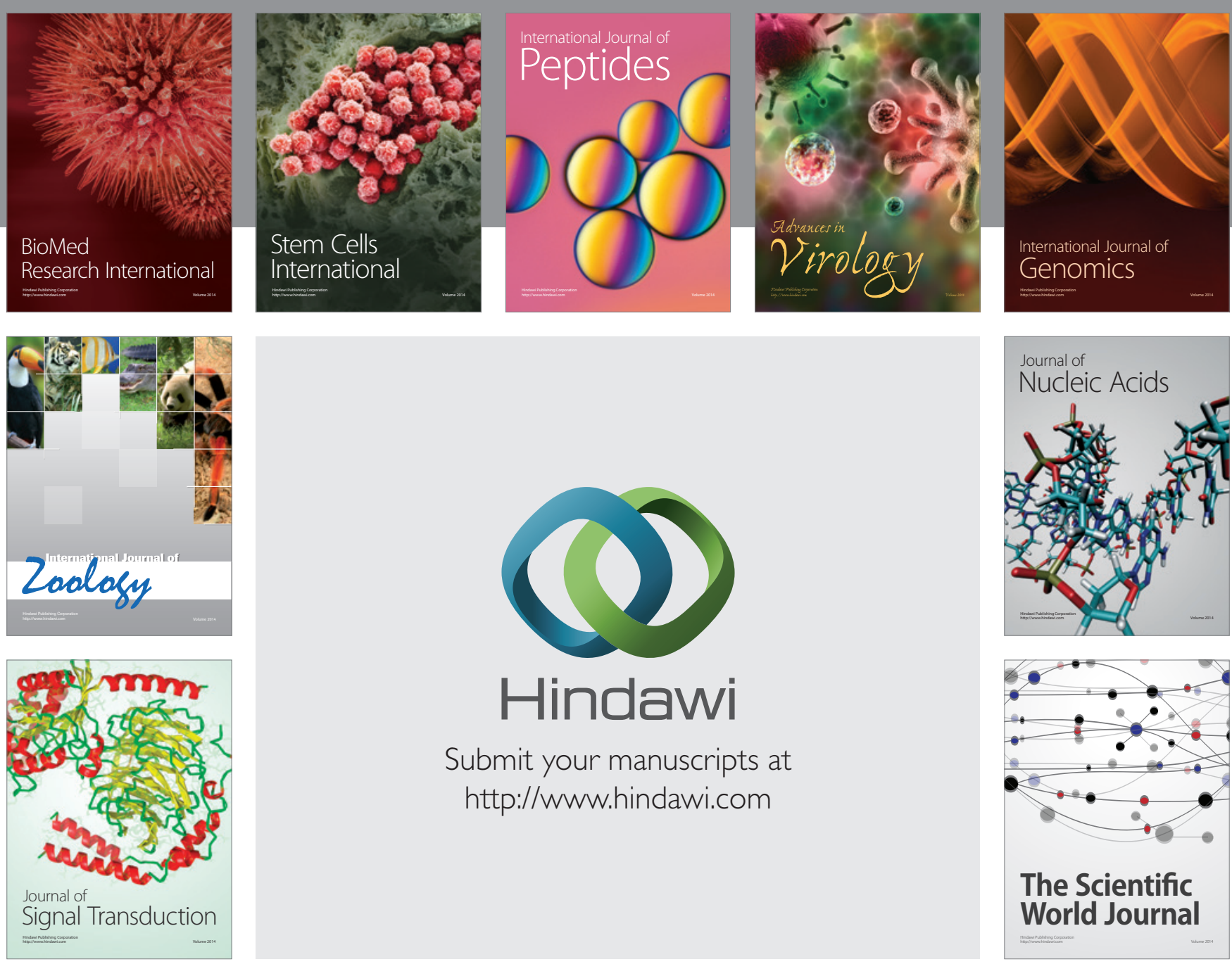

Submit your manuscripts at

http://www.hindawi.com
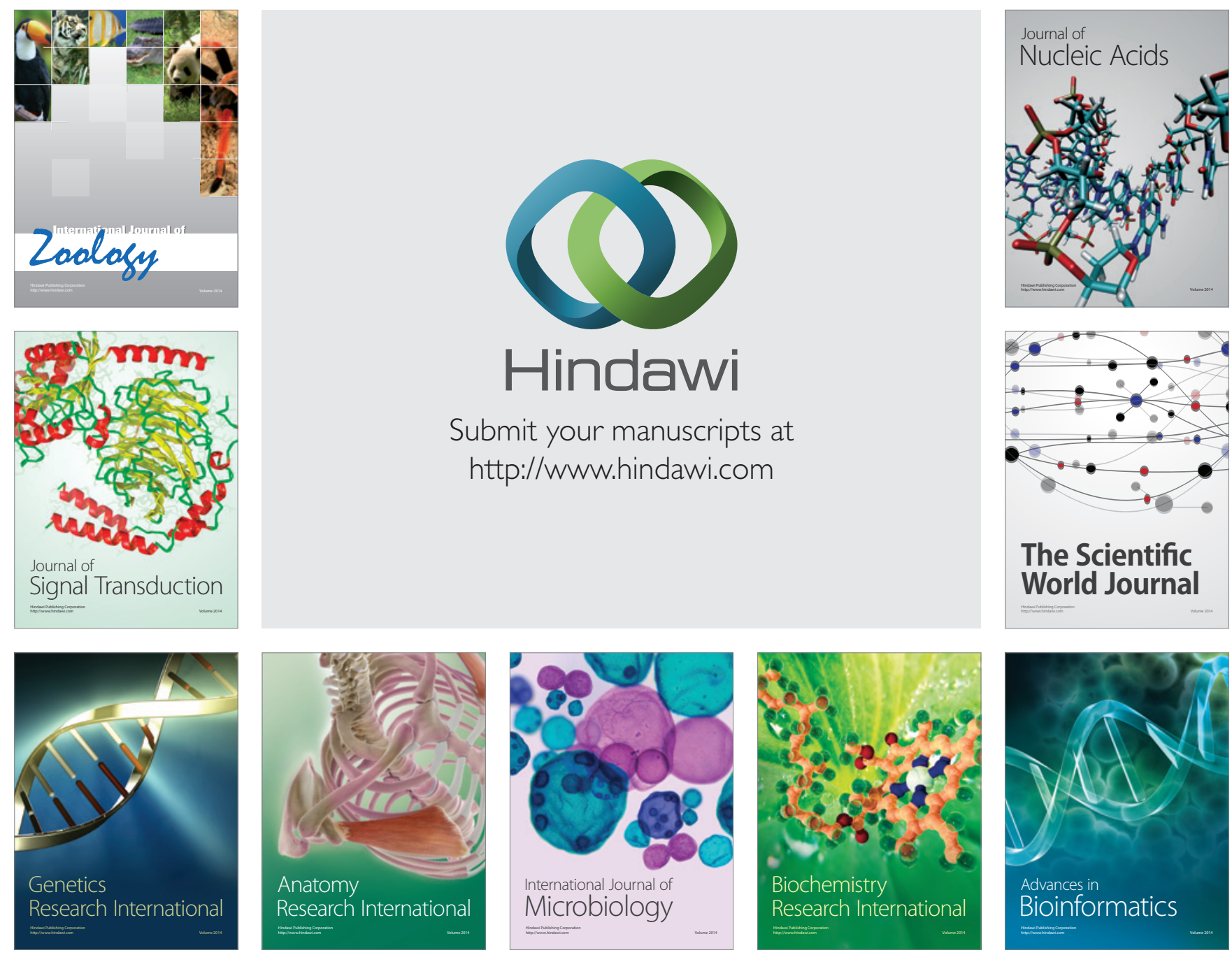

The Scientific World Journal
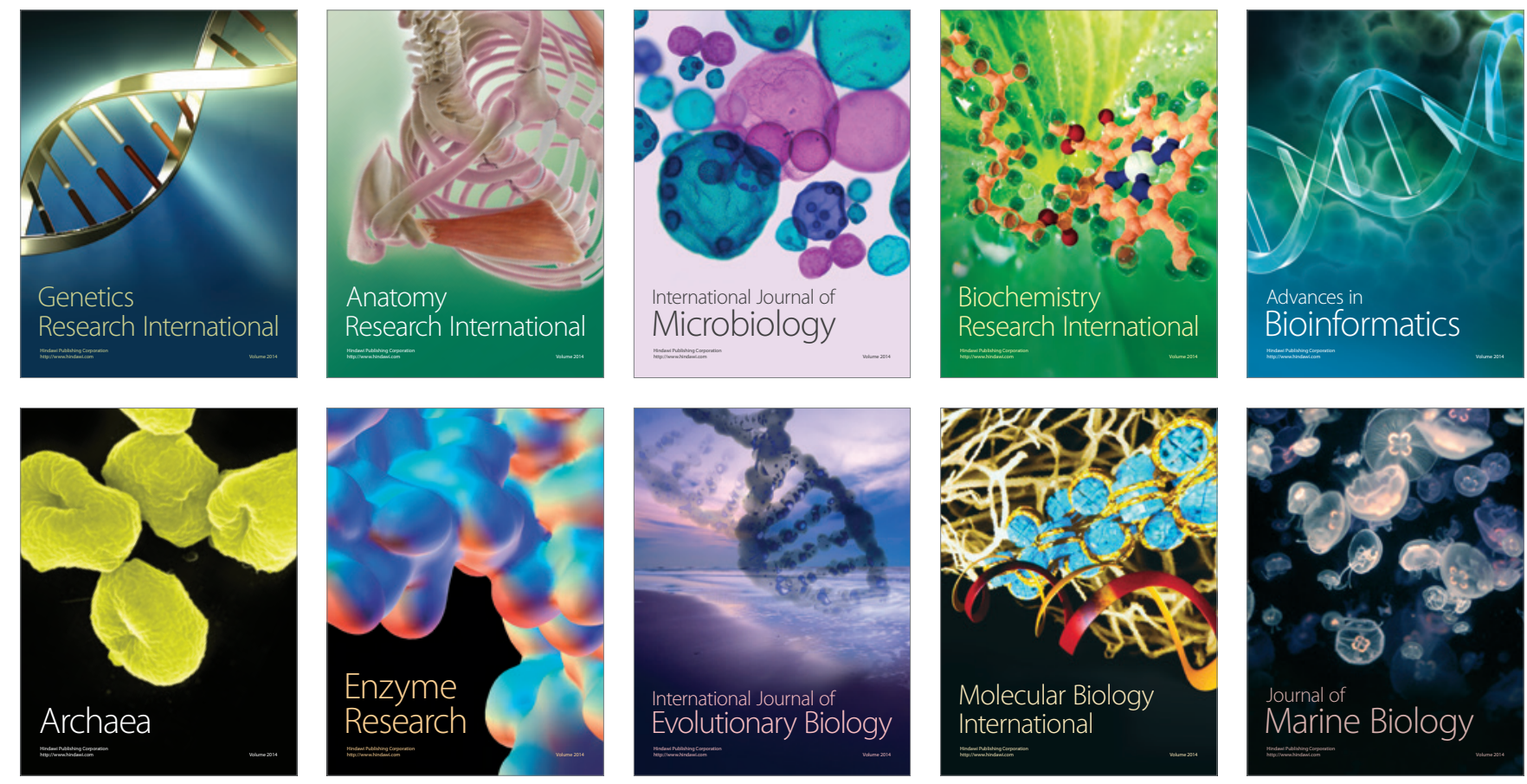